\title{
MALARIA IN ANCIENT GREECE.
}

THE Hippocratic writings mention tertian and quartan fevers. These fevers almost certainly occurred

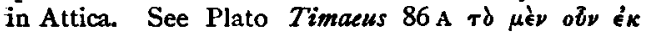

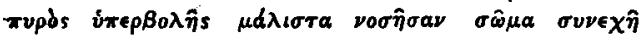

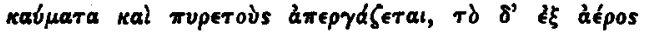

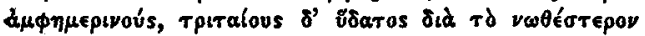

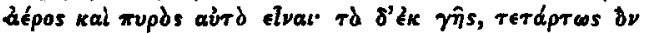
v

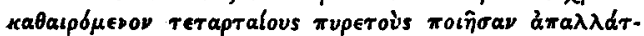

тетal $\mu \delta \lambda$ is.

Compare with this Sir P. Manson Lectures on Tropical Diseases (1905) p. I53. 'Any febrile complaint with a definite tertian or quartan periodicity is certainly malarial. $N_{0}$ other infection exhibits this type of periodicity.'

Perse School, Cambridge.
W. H. S. JONES.

\section{REPORTS}

\section{OXFORD PHILOLOGICAL SOCIETY.-HILARY TERM, I907.}

ON Feb. Ist, at Christ Church, Mr. MYRES read a paper on 'The Growth of the Pelasgian Theory.' The paper has since been pablished in the Tournal of Hellenic Studies.

On Feb. 8th, in Wadham College, Mr. H. P. RichaRDS discussed some passages in the Republic of Plato.

On Feb. I5, in St. John's College, Mr. FotherINGHAM read a paper on 'The Thalassocracies in Eusebius.' The paper has been published in the J.H.S.

On Feb. 22, in University College, Mr. FarQUHARson read a paper on 'The Names of Aelius Caesar, adopted son of Hadrian.'

An attempt was made (I) to prove that Aelius Caesar did not bear the cognomen Verus; (2) to show the origin of the confusions in Historia Augusta as to his name.

(I) The monuments nowhere give to this prince the name Verus. Before adoption he is $\mathrm{L}$. Ceionius Commodus, after L. Aelius Caesar. His ancestors (consulares) bear the names Ceionius Commodus. His son is known (till the death of Pius) as L. Aelius Aurelius Commodus. Precisely upon his accession he becomes on monuments and coins L. Aurelius Verus. These evidences agree with Capitolinus' explicit statements that Marcus (son of M. Annius Verus) gave his own name, 'quasi pater,' to Lucius, when he took him as colleague. From this date Marcus drops the cognomen Verus, his favourite name as Caesar. He takes instead the cognomen Antoninus, as Pius upon accession had taken that of Hadrianus. To emphasize the dynastic succession, based upon the fiction of adoption, he gives Lucius his own birth-name Verus. This view is abundantly illustrated and confirmed from the imperial coins.

(2) Later writers invent pedigrees for L. Aurelius Verus, giving to his father and grandfather the names Aurelius, Verus, and even Annius. At the same time is current the directly contradictory (and false) theories that Marcus was father by adoption of Verus, or was his blood relative. Thus 'quasi pater' becomes in Spartianus 'pater.'

The truth is that the name Verus came from his adoptive brother,. as the name Aurelius from his adoptive father.
Mr. ToD read a note upon 'A Statute of a Greek Thiasos.'

On March Ist, in Balliol College, Mr. BaILEy read a paper on 'The Theory of Anaxagoras.'

On March 8th, in St. John's College, Mr. HaLL read a paper on 'Knoke's Theory of the Aristotelian Katharsis."

On March 15th, in Trinity College, Mr. H. STuART Jones read a paper on "The Second Dacian War of 'Trajan.'

His. object was to show that in the first campaign of this war the Daciansi crossed the Danube, invad. ing the province of Moesia and compelling Trajan to hasten to the relief of the menaced garrisons by the route from Lissus to Naissus, and thence to the Danube. He admitted that Cassius Dio, in stating that after the close of the first Dacian war Decebalus

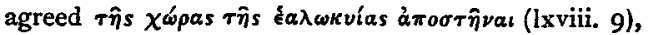
meant that the territory conquered by Trajan was to be evacuated (cp. the same phrase in lxviii. 22, $\tau \hat{\eta} s$

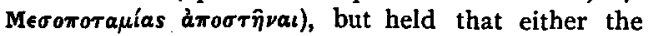
conditions of peace were never completely fulfilled, or that by some means Decebalus was able to bring about the departure of the Roman troops from:Dacia, if not to expel them by force : since the reliefs of the column, when rightly interpreted, clearly showed that Trajan in the first campaign of the second war was engaged on the right bank of the Danube. The second series of reliefs opens with a 'continuous' narrative passage depicting Trajan's journey to the seat of war. The port of departure is universally agreed to be Ancona; but, whereas Petersen thinks that Trajan first coasted up the Adriatic to Rimini and Ravenna and thence crossed to an Istrian port, en route for Sirmium, Cichorius holds that he crossed to Iader, proceeded by Scardona to Salonae, and thence marched to Sirmium. Petersen's criticisms on Cichorius' interpretation are in some respects justified, but be seems to be quite wrong in supposing that Trajan at first followed the-Italian coast-line. After landing at the port rightly identified by Cichorius as Iader, Trajan is seen paying a visit of inspection to an inland camp garrisoned by legionaries. This could not possibly be placed in Italy (as Petersen's theory demands) but may be Burnum, at one time the headquarters of a legion, and still probably garrisoned by a detachment : it is indeed very likely 